<総 説 $>$

(受理 : 平成 28 年 8 月 5 日)

\title{
構造制御された可溶性シルセスキオキサンポリマー Soluble Silsesquioxane Polymers with Controlled Structures
}

\author{
金子芳 郎* \\ Yoshiro KANEKO
}

\section{1.はじめに}

接着・粘着剤は，その固化方法によって乾燥固化型，化 学反応型，熱溶融型，感圧型等に分類されるが，これらの いずれのタイプにおいても有機高分子は適用可能であり, その意味で有機高分子は接着・粘着剤に適している材料で あると言える。一方で，無機系の接着剤もセメントや水ガ ラス等は実用的に利用されており，これらの無機系接着剂 は無機材料の特徴である耐熱性や耐久性, さらに無機物同 士の接着性に優れる等有機高分子系接着剤にはない機能を 有する。しかし, 通常の無機材料は溶解性や分散性が悪く (再溶解や再分散が困難なものが多く), また融点も非常に 高いため, 無機系接着剤は有機高分子系接着剤に比べると その種類が限定される。このことから新たな無機材料（無 機高分子）の探索は, 新規無機系接着剂の開発において重 要であると考えられる。

一方で近年，無機骨格材料であるシルセスキオキサン (Silsesquioxane: SQ) が基礎掞よび応用研究の両分野で 注目されている。SQとは三官能性のアルコキシシランや クロロシラン等の加水分解とその後に続く縮合反応によっ て得られる化合物の総称であり（図 1)，シロキサン（Si$\mathrm{O}-\mathrm{Si}$ ) 結合由来の熱的・力学的・化学的安定性を有する ことに加えて, 有機置換基の存在により有機物（ポリマー 等）との相溶性や接着性に優れるあのもあり，幅広い分野 で研究展開されている1,2)。かご（ケージ）型, 不完全か ご型，ダブルデッカー型，ラダー（はしご）型，ランダム 型等，様々な構造の SQ が存在することも，これらの化合 物群が多くの分野で注目される理由の 1 つであろう（図 1)。 しかし，研究の中心はかご型の可溶性オリゴ SQ（POSS:

\footnotetext{
$*$ 鹿児島大学 学術研究院理工学域工学系 鹿児島市郡元 1-21-40 干 890-0065

Research Field in Engineering, Science and Engineering Area, Research and Education Assembly, Kagoshima University 1-21-40 Korimoto, Kagoshima 890-0065, Japan
}

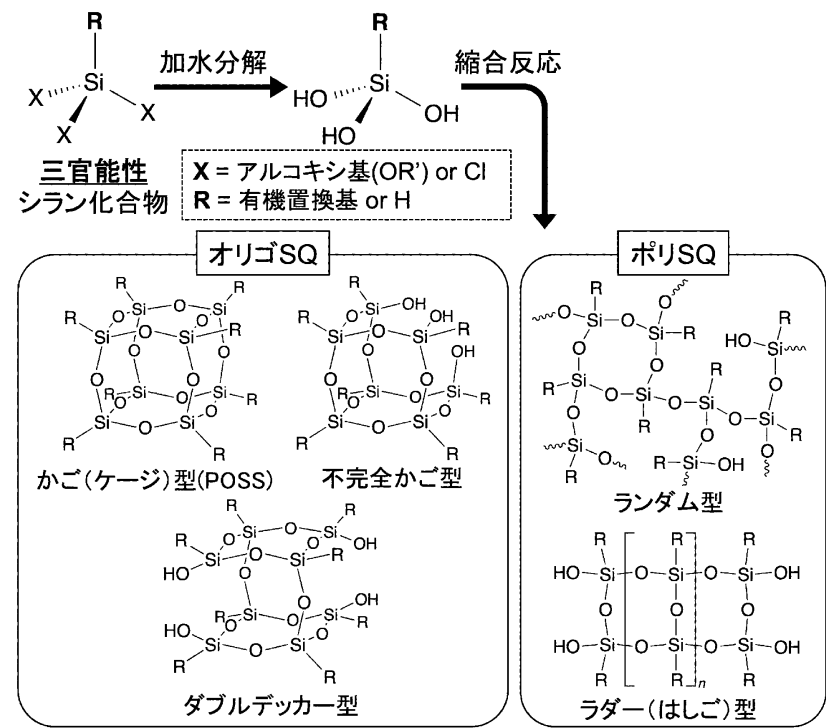

図 1 シルセスキオキサン（SQ）の合成と主な構造

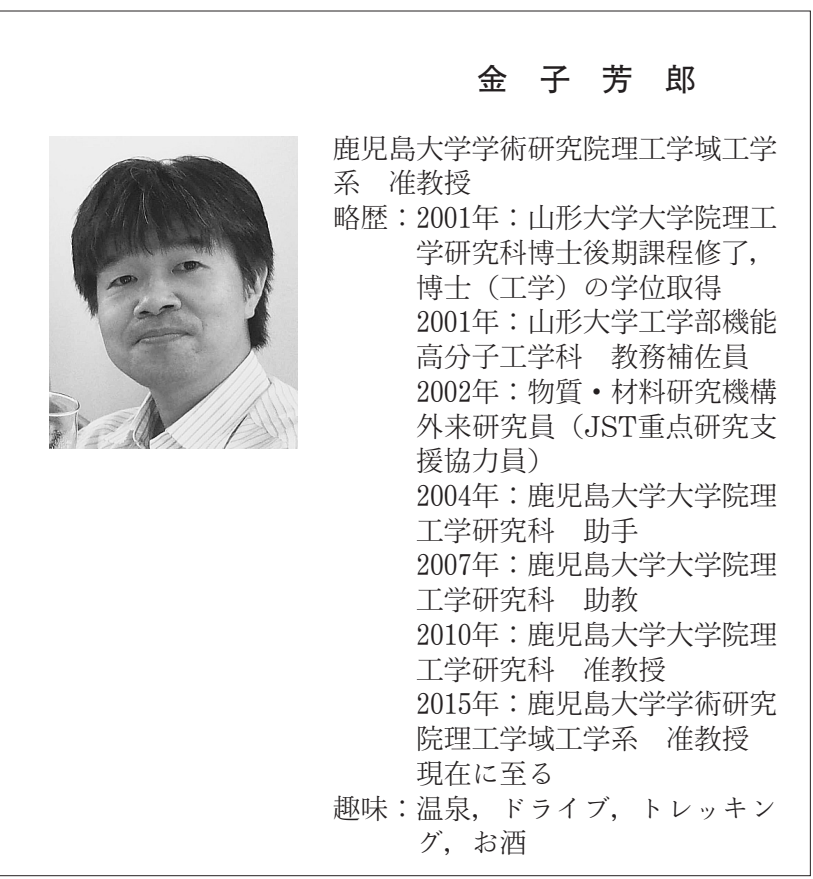


polyhedral oligomeric silsesquioxane の略称）やランダ ム型の不溶性ポリ SQ であり ${ }^{3)}$ ，ラダー型のような規則的 な分子構造を屯つ可溶性ポリ SQの合成に関する研究例は 少ない。高分子量の可溶性ポリ SQの合成が難しいのは, 原料として三官能性のシラン化合物が用いられるためであ る。これらのシラン化合物の加水分解/重縮合反応によっ てポリ SQ は合成されるが，三官能性モノマーであるため 通常は三次元方向に分子鎖が生長した不溶性のネットワー クポリマー（ランダム型ポリ SQ）が形成される。ラダー 構造のように 1 次元方向に分子鎖を生長させるためには何 らかの駆動力が必要であり，そのための側鎖置換基は芳香 族系に限られていた ${ }^{4 \sim 8)}$ 。このような背景より, SQ 成分含

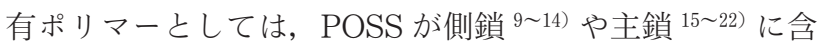
まれるポリマーが，これまでに基礎と応用の両分野で広く 研究されている。しかし，これらのPOSS 含有ポリマーは 通常多段階の反応を必要とし, 汎用性において課題が残る。

本稿では，接着・粘着剤としての性能・機能についての 検討までには至っていないが，そのポテンシャルを有する と思われる構造制御された可溶性 SQ ポリマーやオリゴマー の簡便な合成，構造解析，物性について紹介する。

\section{2. 可溶性ラダー状ポリシルセスキオキサンの合成}

\section{1 側鎖にアンモニウム基をもつラダー状ポリシルセ スキオキサンの合成}

筆者らは，原料（モノマー）である 3 -アミノプロピル トリメトキシシラン (APTMS) に塩酸 $(\mathrm{HCl})$ 等の強酸 水溶液を過剩量 $(\mathrm{HCl} / \mathrm{APTMS}(\mathrm{mol} / \mathrm{mol})=1.5$ 以上） 加えて室温で擋汼し，その後開放系で加熱して溶媒（HCl 水溶液）を蒸発させることで加水分解/重縮合反応（いわ
ゆるゾルーゲル反応）を行ったところ，固体状態ではへキ サゴナル積層体を形成するアンモニウム側鎖置換基含有の 水溶性ロッド状/ラダー状ポリ $\mathrm{SQ}\left(\mathrm{PSQ}-\mathrm{NH}_{3} \mathrm{Cl}\right.$ ) が得 られることを見出した（図 $2 \mathrm{a}$ ) 23 31)。重縮合反応が進行 しシロキサン骨格が形成されたことを，IR（ $\mathrm{Si}-\mathrm{O}-\mathrm{Si}$ 結 合由来の吸収ピークの存在), ${ }^{29} \mathrm{Si} \mathrm{NMR}\left(\mathrm{T}^{3}\right.$ ピークの積 分比が $90 \%$ 以上（図 3a））㧍よび分子量測定（静的光散 乱測定による Zimm プロット法：重量平均分子量 $M_{\mathrm{w}}=$ $1.0 \times 10^{4} \sim 1.4 \times 10^{4}$ ) により確認した。

$\mathrm{PSQ}-\mathrm{NH}_{3} \mathrm{Cl}$ は比較的高い分子量であるにもかかわら ず可溶性であったため，ラダー構造のような 1 次元構造体 である可能性が高い。Brown らの報告以来 ${ }^{4)}$ ， IR スペク

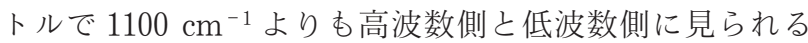
$\mathrm{Si}-\mathrm{O}-\mathrm{Si}$ 結合由来の 2 本の吸収ピークの存在や, MarkHouwink の式から剛直性鎖かどうかの議論によって，ポ リ SQのラダー構造の形成が議論されてきた。しかし，こ れらは直接的なラダー構造のための証拠とは言えず，未だ にポリ SQのラダー構造を証明する分析法については確立 されていない。一方で，ラダー状ポリ SQ は以下の性質を 全て満たす：(1)溶媒に可溶である，(2)高分子量体である， (3)一次元構造体である, (4)一次元構造体の直径が数 $\mathrm{nm}$ 程 度である，(5) ${ }^{29} \mathrm{Si} \mathrm{NMR} \mathrm{スペクトルにおいて} \mathrm{T}{ }^{3}$ ピークの割 合が高い。このことから筆者らは，これらの 5 つの条件を同 時に満たすポリ SQ が得られれば図 4 に示す構造体ではな いことを証明でき，消去法ではあるがラダー状構造を形成 していると見なして良いのではないかと提唱している26 31)。

実際に $\mathrm{PSQ}-\mathrm{NH}_{3} \mathrm{Cl}$ の構造について検討したところ，

(1)水に可溶で，(2) $M_{\mathrm{w}}$ は 1 万以上（重合度 DP は約 70 以 上）であり，図 $3 \mathrm{~b}$ に示す XRD パターンより(3)へキサゴ

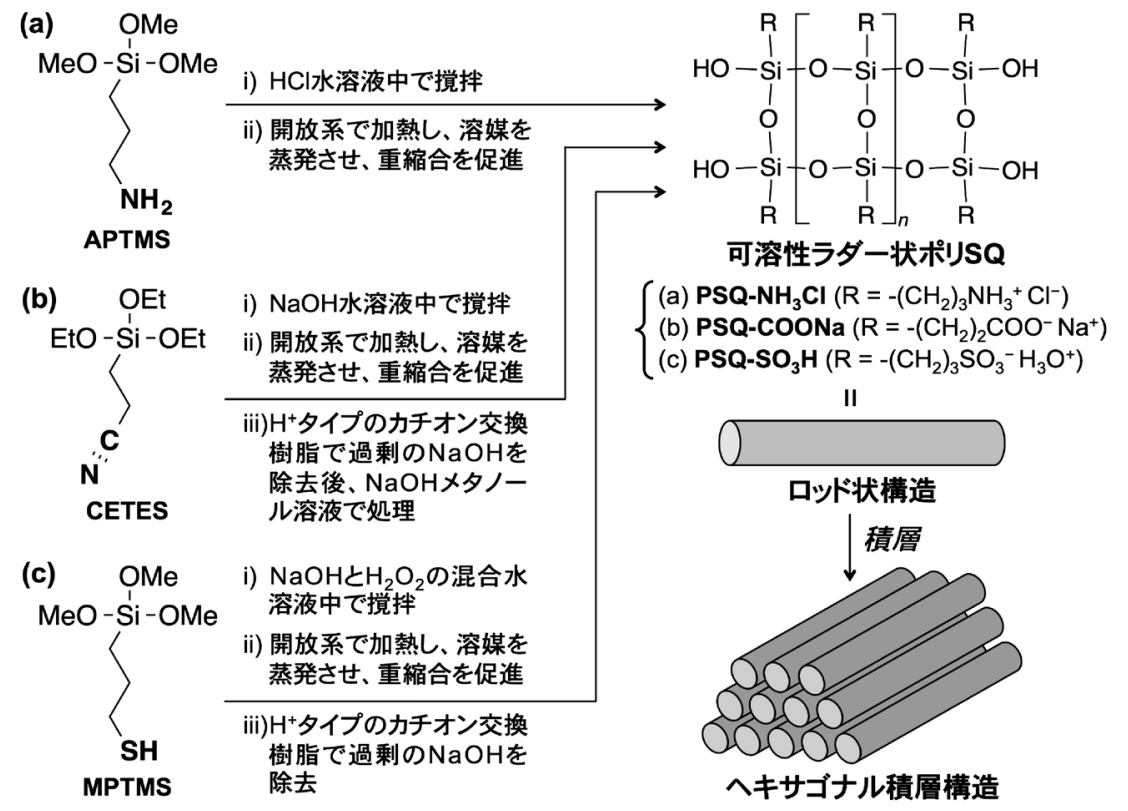

図 2 ヘキサゴナル相に積層する可溶性ロッド状/ラダー状ポリ $\mathrm{SQ}$ ：(a) $\mathrm{PSQ}-\mathrm{NH}_{3} \mathrm{Cl}$, (b) $\mathrm{PSQ}-\mathrm{COONa}$, (c) $\mathrm{PSQ}-\mathrm{SO}_{3} \mathrm{H}$ の合成 

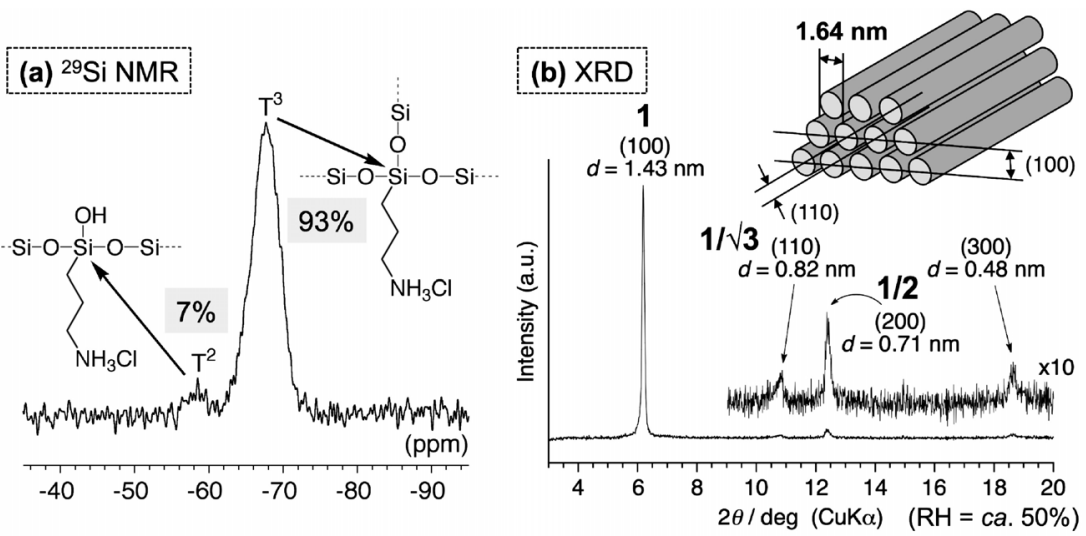

図 $3 \mathrm{PSQ}-\mathrm{NH}_{3} \mathrm{Cl}$ の (a) ${ }^{29} \mathrm{Si} \mathrm{NMR} \mathrm{スペクトルと（b）} \mathrm{XRD}$ パターン

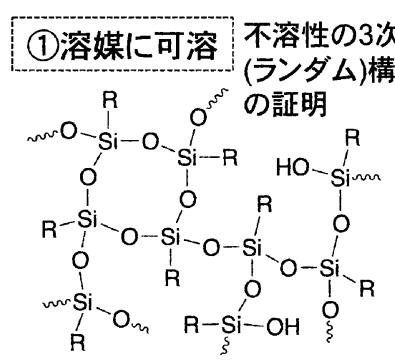

(2)高分子量体

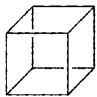

かご型やランダム型などの オリゴSQでないことの証明

\section{(5)Tピークの割合が高い(29Si NMR)

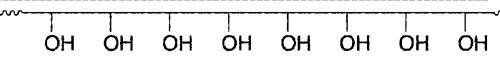 \\ ポリマーの両末端以外にシラノール基が \\ ほとんど存在しないことの証明 \\ ( ${ }^{*} T^{3}=$ 3箇所のシロキサン結合をもつSi原子}

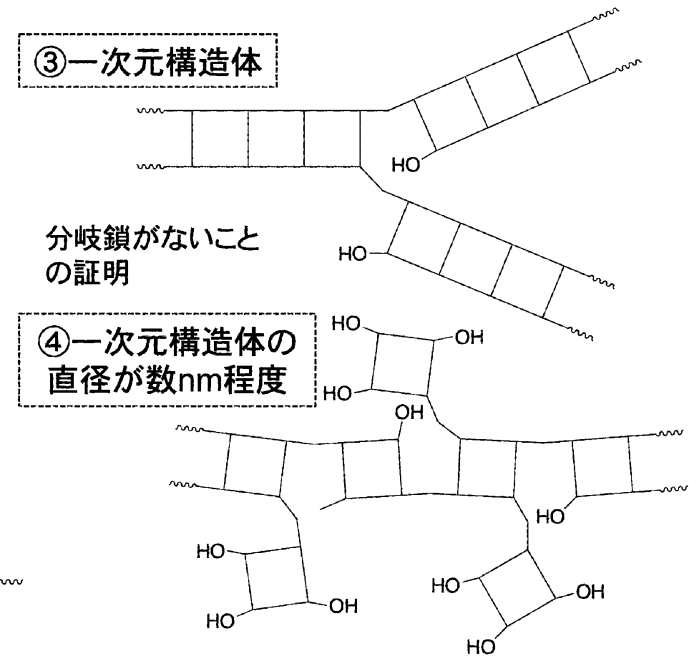

図 4 ポリ SQ のラダー状構造を証明するための必要条件

ナル相の形成を表す $d$ 值の比が $1: 1 / \sqrt{3}: 1 / 2$ である 3 本の 回折ピークが観測され（これは，比較的高いアスペクト比 を有する一次元ロッド状構造体の形成を示す)，(4)これら の回折ピークの $d$ 值より算出されたロッドの直径（分子 の幅）は $2 \mathrm{~nm}$ 以下であった。さらに(5) ${ }^{29} \mathrm{Si} \mathrm{NMR}$ スペク トルより $\mathrm{T}^{3}$ ピークの積分比が $93 \%$ であり（図 3a），図 4 中の (1)〜(5)の条件を全て満たしていた ${ }^{26 \sim 31) 。 す な わ ち, ~}$ 分子の幅が $2 \mathrm{~nm}$ 以下の限られた空間の中で，DP が 70 以上のポリ $\mathrm{SQ}$ が高い割合で $\mathrm{T}^{3}$ 構造を有していることを 考えると, $\mathrm{PSQ}-\mathrm{NH}_{3} \mathrm{Cl}$ はシロキサン結合からなる 8 員 環が一次元方向につながったラダー状構造を有していると 考えるのが妥当であろう（ただし，ポリマーの両末端以外 に全くシラノール基のない“完全な”ラダー構造である確 証はない)。

通常，三官能性シラン化合物の加水分解/縮合反応を行 うと，不規則な 3 次元ネットワーク構造体（ランダム構造 体）を形成し不溶性の材料となりやすい。しかし，本手法
ではモノマー中のアミノ基と触媒の強酸から形成される塩 （イオン対）の働きにより，ランダム型のポリ SQ の生成 を抑制したと考えている。このことは，アンモニア $\left(\mathrm{NH}_{3}\right)$ 水溶液を触媒に用いた APTMS の加水分解/縮合反応では, 不溶性のランダム型ポリ SQ が形成されたことからも支持 される。同様な構造の水溶性ポリ $\mathrm{SQ}$ は，3-(2-アミノエ チルアミノ）プロピルトリメトキシシラン（AEAPTMS） のような他のアミノ基含有有機トリアルコキシシランから あ同様の反応により合成可能であった ${ }^{32)}$ 。また，対イオ ンが塩化物イオンである $\mathrm{PSQ}-\mathrm{NH}_{3} \mathrm{Cl}$ は水溶性であるが, これをオクタン酸等の長鎖アルキルカルボン酸に置換（イ オン交換）するとエ夕ノール等のアルコール類にも可溶な ポリ SQが得られる23)。

2.2 側鎖にアニオン性置換基をもつラダー状ポリシル セスキオキサンの合成

本項では，側鎖置換基と対イオンの電荷の組み合わせが 
$\mathrm{PSQ}-\mathrm{NH}_{3} \mathrm{Cl}$ とは逆であるアニオン性置換基含有ラダー 状ポリ SQの合成について説明する。

筆者らは, 加水分解によりカルボキシル基に变換可能な シアノ基含有の有機トリアルコキシシラン（2-シアノエ チルトリエトキシシラン：CETES）を原料に用いて，水 酸化ナトリウム $(\mathrm{NaOH})$ 水溶液中での加水分解/縮合反 応を行ったところ，カルボキシレート基含有ロッド状/ラ ダー状ポリ SQ (PSQ-COONa) が得られることを見出し た (図 $2 \mathrm{~b})^{33)} 。 M_{\mathrm{w}}$ は $2.7 \times 10^{3}$ であり前述の $\mathrm{PSQ}-\mathrm{NH}_{3} \mathrm{Cl}$ よりあ低い值であったが, XRD パターンからは $d$ 值の比 が $1: 1 / \sqrt{3}: 1 / 2$ である 3 本の回折ピークが観測され, ヘキサ ゴナル相を形成するようなロッド状構造体であることが分 かり, ${ }^{29} \mathrm{Si} \mathrm{NMR}$ スペクトルからは比較的高い割合の $\mathrm{T}^{3}$ ピークが見られたことより, ラダー状構造の形成が示唆さ れた。

さらに，酸化反応によりスルホ基（スルホネート基）に 变換可能なメルカプト基を有する有機トリアルコキシシラ ン（3-メルカプトプロピルトリメトキシシラン: MPTMS) を, 過酸化水素水と $\mathrm{NaOH}$ からなる混合水溶液中で反応 （メルカプト基の酸化反応およびトリメトキシシリル基の加 水分解/縮合反応）したところ，ヘキサゴナル積層構造を有 する可溶性のスルホ基含有ロッド状/ラダー状ポリ SQ (PSQ $-\mathrm{SO}_{3} \mathrm{H}$ ) が得られた (図 $2 \mathrm{c}$ ) ${ }^{34)}$ 。 ${ }^{29} \mathrm{Si} \mathrm{NMR}$ スペクトルよ り $\mathrm{T}^{3}$ ピークが主に観測され（積分比 $84 \%$ )， $M_{\mathrm{w}}$ は $6.8 \times$ $10^{3}$ と見積もられた。また, XRD パターンより $d$ 值の比 が $1: 1 / \sqrt{3}: 1 / 2$ である 3 本の回折ピークが観測され, ヘキ サゴナル相を形成していたことから，比較的高いアスペク 卜比を有する一次元構造体であることが示唆され, 回折ピー クの $d$ 值より算出されたロッドの直径（分子の幅）は $2 \mathrm{~nm}$ 以下であることが分かった。以上の結果より，前述の $\mathrm{PSQ}-\mathrm{NH}_{3} \mathrm{Cl}$ 等と同様に $\mathrm{PSQ}-\mathrm{SO}_{3} \mathrm{H}$ む図 4 に示す 5 つ
の条件を満たしており, ラダー状構造の形成が示唆された。 ナフィオンに代表されるように，スルホ基含有ポリマー は固体高分子形燃料電池 (PEFC) の固体電解質（プロト ン伝導体）として期待されている材料であるが，ナフィオ ンは $100^{\circ} \mathrm{C}$ 付近にガラス転移点が存在するため,この温度 以上では作動できない。このことから，熱的物性に優れる スルホ基含有無機ポリマーの開発が期待されており, PSQ $-\mathrm{SO}_{3} \mathrm{H}$ はその候補と考えられる。そこで, $\mathrm{PSQ}-\mathrm{SO}_{3} \mathrm{H}$ の加湿条件下でのプロトン伝導度を測定したところ，

$>10^{-2} \mathrm{~S} \mathrm{~cm}^{-1}\left(80^{\circ} \mathrm{C}, 30 \sim 90 \% \mathrm{RH}\right)$ であり比較的高い值 であった。

\section{3 側鎖に様々な疎水基をもつラダー状ポリシルセス キオキサンの合成}

前述の $\mathrm{PSQ}-\mathrm{NH}_{3} \mathrm{Cl}$ の側鎖にはアンモニウム基（アミ ノ基）が存在するため，カルボン酸塩化物やカルボン酸無 水物と容易に反応でき，アミド結合やイミド結合を介して 種々の置換基を側鎖へ簡便に導入することが可能である。 そこで本項では, $\mathrm{PSQ}-\mathrm{NH}_{3} \mathrm{Cl} へ の$ 様々な疎水性置換基 の共有結合による導入と, 得られたポリ SQの熱物性につ いて紹介する。

疎水性カルボン酸塩化物として, ベンゾイルクロリド $(\mathrm{PhCOCl})$, シクロヘキサンカルボニルクロリド $\left(\mathrm{CyC}_{6} \mathrm{COCl}\right)$, ヘプタノイルクロリド $\left(\mathrm{C}_{6} \mathrm{COCl}\right)$, ドデカノイルクロリ ド $\left(\mathrm{C}_{11} \mathrm{COCl}\right)$ を用いて, トリエチルアミン存在下 $\mathrm{DMF}$ と 水の混合溶媒中で $\mathrm{PSQ}-\mathrm{NH}_{3} \mathrm{Cl}$ と反応させることで, ア ミド結合を介して側鎖に疎水基をもつポリ $\mathrm{SQ}$ ( $\mathrm{PSQ}-\mathrm{Ph}$, $\mathrm{PSQ}^{-} \mathrm{CyC}_{6}, \mathrm{PSQ}-\mathrm{C}_{6}, \mathrm{PSQ}-\mathrm{C}_{11}$ ) を合成した（図 5a〜 d) ${ }^{35)}$ 。一方, 疎水性カルボン酸無水物としてフタル酸無 水物を用いて，トリエチルアミン存在下 DMSO と水の混 合溶媒中で $\mathrm{PSQ}-\mathrm{NH}_{3} \mathrm{Cl}$ と反応させることでフタルアミッ

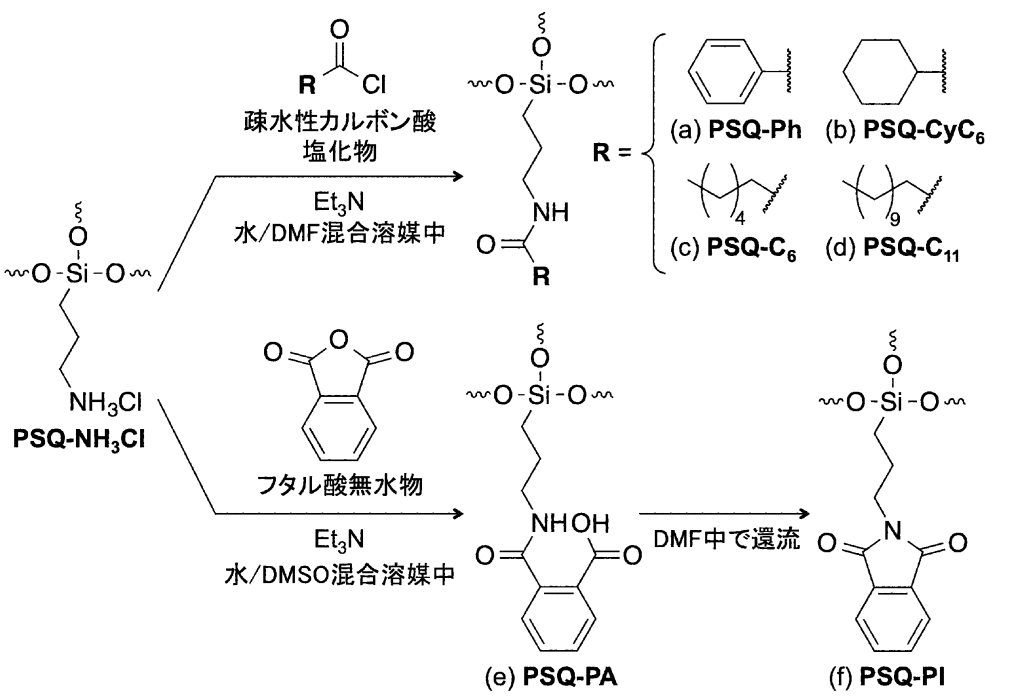

図 5 側鎖に疎水性置換基を有する可溶性ポリ $\mathrm{SQ}$ ：(a) $\mathrm{PSQ}-\mathrm{Ph}$, (b) $\mathrm{PSQ}-\mathrm{CyC}_{6}$, (c) $\mathrm{PSQ}-\mathrm{C}_{6}$, (d) $\mathrm{PSQ}-\mathrm{C}_{11}$, (e) PSQ-PA, (f) PSQ-PI の合成 
表 1 ポリ SQ の溶解性, 分子量, 分子量分布, 熱分解温度

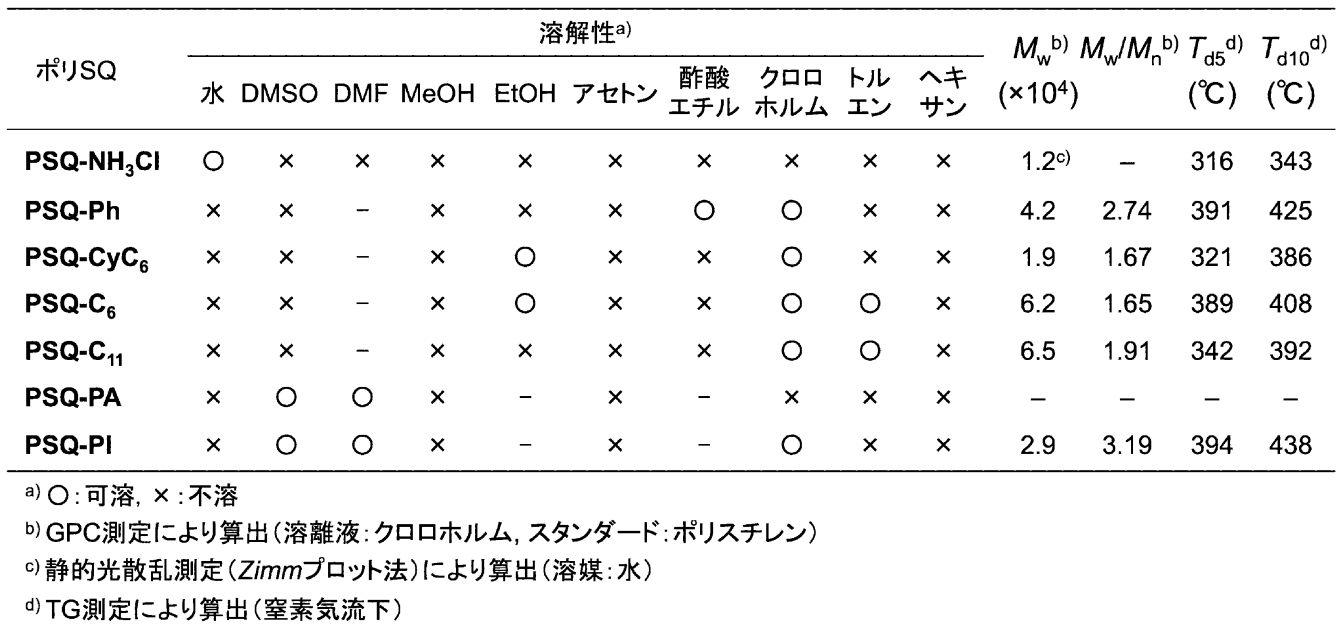

ク酸含有ポリ $\mathrm{SQ}$ (PSQ-PA) を合成し（図 5e), $\mathrm{PSQ}-$ $\mathrm{PA}$ を DMF 中で還流摚拌することでフタルイミド基含有 ポリ $\mathrm{SQ}$ (PSQ-PI) を得た（図 5f） ${ }^{36)}$ 。

これらのポリ SQ は種々の有機溶媒に可溶であり，また GPC 測定により算出された $M_{\mathrm{w}}$ は比較的高く（表 1), い ずれも成膜性のあるポリマーであった。一方，TG 測定 （窒素気流下）に上り熱分解温度を求めたところ，特に PSQ-Ph，PSQ- $\mathrm{C}_{6}$ 抢よび PSQ-PI の 10\%重量減少温度 （ $T_{\mathrm{d} 10}$ ) に扔いては $400^{\circ} \mathrm{C}$ を越え（表 1$)$ ，非常に高い熱安 定性を示すことが分かった。

\section{3. 超強酸触媒によるイオン性かご型オリゴシルセ スキオキサン（POSS）誘導体の合成}

\section{1 側鎖にアンモニウム基をもつ POSS の簡易合成}

POSS は構造が規制されたシロキサン結合骨格をもつ直 径が約 $2 \mathrm{~nm}$ 以下の粒子であり, 様々な媒体に対して分散 性に優れる化合物である。これまでに様々な種類の POSS が合成されて抢り ${ }^{37)}$ ，八イブリッドの分野を中心に広く 利用が検討されている。一方で，代表的な反応性基含有 POSS として 3-アミノプロピル基含有 POSS (AP-POSS) が知られる。AP-POSS は APTMS 等の 3-アミノプロピ ルトリアルコキシシランの加水分解/縮合反応により得ら れるが，通常は重合（多分子間での反応）を抑制するため に希薄溶液中，穏やかな条件下で反応し，徐々に析出して くる沈殿物を回収する手法で合成されている38)。そのため, 一般に AP-POSS の合成には長時間の反応が必要である にもかかわらず，比較的低い収率となってしまう。

筆者弓は，前述の $\mathrm{PSQ}-\mathrm{NH}_{3} \mathrm{Cl}$ 合成のための原料であ る APTMS の加水分解/縮合反応において, 触媒を強酸の $\mathrm{HCl}\left(\mathrm{p} K_{\mathrm{a}}=-3.7\right)$ 水溶液から超強酸のトリフルオロメ夕 ンスルホン酸（HOTf, $\mathrm{p} K_{\mathrm{a}}=-13$ ) 水溶液に代えて, PSQ $-\mathrm{NH}_{3} \mathrm{Cl}$ 合成の場合と同様に開放系で加熱し溶媒を蒸発 させることで加水分解/縮合反応を行ったところ， $\mathrm{AP}-$
POSS (8 量体 $\left(\mathrm{T}_{8}\right)$ が主生成物でわずかに 10 量体 $\left(\mathrm{T}_{10}\right)$ 屯含む）が簡便に合成できることを見出した（図 6a） ${ }^{399}$ 。 生成物の収率は $93 \%$ であり，これまでに報告されている $\mathrm{AP}-\mathrm{POSS}$ の合成に打ける収率と比較して向上した。さ らに全体の反応時間は $5 \sim 6$ 時間程度であり従来法と比較 して飛躍的に短くなった。一方，AEAPTMS を用いた同 様の反応からも POSS（AEAP-POSS）が高収率・短時 間で得られることを見出しており (図 $6 \mathrm{~b})^{40)}$ ，原料中のア ミノ基と触媒の超強酸から形成される塩（イオン対）が POSS 形成のための重要因子であることが分かった。

以上の結果より, 開放系で加熱し溶媒を蒸発させて縮合 反応を促進させる筆者らの手法において，HOTf のような 超強酸の水溶液を触媒に用いるとゲル化やポリマー化は全 く起こらず POSS が形成され， $\mathrm{HCl}$ のような強酸水溶液 を触媒に用いた場合にはロッド状/ラダー状のポリ SQ が 得られることが分かった。そこで，他の触媒についても検 討を行ったところ，強酸である硝酸（ $\mathrm{p} K_{\mathrm{a}}=-1.8 ）$ やリ フルオロ酢酸（ $\mathrm{p} K_{\mathrm{a}}=0.3 ）$ の水溶液から得られた生成物 の $\mathrm{XRD}$ パターンからは, $\mathrm{PSQ}-\mathrm{NH}_{3} \mathrm{Cl}$ と同様なへキサ ゴナル積層構造を表す回折ピークが観測されラダー状ポリ $\mathrm{SQ}$ の形成が示唆された。一方, $\mathrm{NH}_{3}\left(\mathrm{p} K_{\mathrm{a}}=9.3\right)$ 水溶液 中での APTMS の加水分解/縮合反応からは，前述の上う に不溶性のランダム型ポリ SQ が得られた。すなわち, 用いる触媒の種類（ $\left(\mathrm{p} K_{\mathrm{a}}\right)$ により，かご型のオリゴマー (0 次元構造体), ラダー状のポリマー（1 次元構造体）拉 よびランダム型のポリマー（3 次元構造体）を作り分ける ことができることを明らかにした 26 31)。

一方で，対称構造体である POSS は結晶性が高いため に粉末状のものが多く, POSS 単独で光学的に透明な膜を 作製することは困難である。最近中らは，POSS の結晶化 を抑制する手法として，POSS ユニットが連結したダンベ ル型やスタ一型の POSS 誘導体を合成し，POSS の対称 性を低下させることで光学的に透明な膜を形成する手法を 


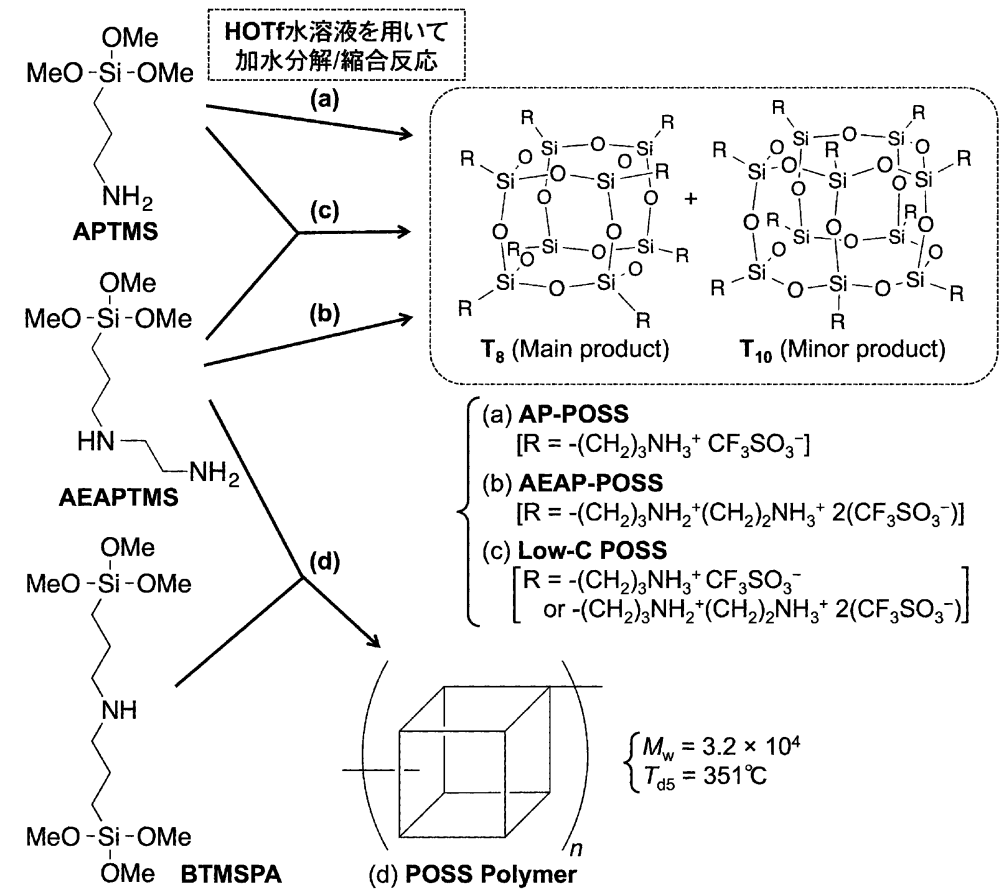

図 6 アンモニゥム基含有 POSS 誘導体：（a）AP-POSS, (b) AEAP-POSS, (c) Low-C POSS, (d) POSS Polymer の合成

報告している ${ }^{41,42)}$ 。

一方筆者らは，2 種類のアミノ基含有有機トリアルコキ シシラン（APTMS と AEAPTMS）の混合物を原料に， HOTf の水溶液を触媒に用いた加水分解/縮合反応を行っ たところ，透明な膜が形成可能な低結晶性 POSS（LowC POSS）が得られることを見出した（図 6c) ${ }^{40)}$ 。前述の POSS と同様に主生成物は $\mathrm{T}_{8}$ で， $\mathrm{T}_{10}$ あわずかに含まれ る混合物であったが，ポリマー化されたものは全く含まれ ていなかった。Low-C POSS を水に溶解してガラス基板 上に塗布し乾燥したところ, 無色透明な膜が得られること を UV-Vis 測定执よび目視観察により確認した。この膜 の XRD パターンからは，回折ピークがほとんど見られ なかったため, POSS の結晶化が抑制されたことが分かっ た。一方，それぞれ単独の側鎖置換基をむつ POSS（APPOSS 拉よびAEAP-POSS）や，これらを水に溶解した 後乾燥して得られた混合物の XRD パターンからはシャー プな回析ピークが観測され，白濁した膜が得られた。 Low-C POSS が低結晶性である理由として，2 種の置換 基が POSS の側鎖にランダムに配置していることにより, 分子の対称性が低下したためと考えている。すなわち， Low-C POSS の膜中には可視光が散乱するような大きさ の結晶ドメインがほとんど存在しないことから透明な膜に なったと推察している。

\subsection{POSS 連結型可溶性ポリマーの簡易合成}

POSS を材料応用する手法の 1 つとして, POSS のポリ マー化がこれまでに検討されている。可溶性の POSS 含 有ポリマーは大きく 2 種類に分類され，1つ目は有機ポリ

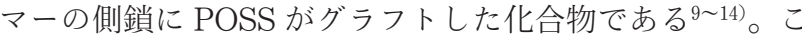
のポリマーを合成するためには，まずシラノール基を有す る不完全 POSS に重合基含有シランカップリング剂をは め込み，得られるPOSS 誘導体を重合することで行う。 2 つ目は POSS がポリマー主鎖中に含まれる化合物である。 このポリマーの代表的な合成法として，シラノール基を含 むダブルデッカー型 $\mathrm{SQ}$ に反応性置換基含有シランカップ リング剤を導入し，これを二官能性モノマーとして用いて 重合する手法が知られる16 19)。また最近中らは，不完全 POSS にアミノプロピル基やビニル基等の反応性基含有シ ランカップリング剂を導入し，導入された箇所の反対側 （対角線上）の Si に隣接しているシロキサン結合のみを選 択的に加水分解して不完全 POSS を形成し，再び反応性 基含有シランカップリング剂を導入することで二官能性モ ノマーを合成する手法を報告している20 22)。これらのモ ノマーの重合によっても POSS がポリマー主鎖中に含ま れる化合物が得られる。これらの POSS 含有ポリマーは, 特に熱物性において優れた特性を示す。一方で，これらの POSS 含有ポリマーを得るためには, 不完全 POSS やダ ブルデッカー型 $\mathrm{SQ}$ の合成まで含めると，多段階の反応や 煩雑な精製過程を必要とし，汎用的な利用を考えるとこれ らポリマーの簡便な合成手法の開拓が望まれる。

前述のように，筆者らは HOTf 水溶液を触媒に用いて APTMS や AEAPTMS，さらにこれらの混合物の加水分 解/縮合反応により，アンモニウム基含有 POSS を高収率・ 短時間で簡便に合成できることを見出している。そこで, POSS の原料となる AEAPTMS と架橋型有機アルコキシ シラン（例えば，ビス [3-(トリメトキシシリル)プロピ 
ル）アミン（BTMSPA））の混合物の HOTf 水溶液中で の加水分解/縮合反応を検討したところ, POSS が連結し た水溶性ポリマー（POSS Polymer）を一段階で合成で きることを見出した（図 6d ${ }^{43)}$ 。

生成物の ${ }^{29} \mathrm{Si} \mathrm{NMR}$ スペクトルからは $\mathrm{T}^{3}$ 構造由来の 2 本のピーク（-66.9 および-68.9 ppm）のみが観測され， $\mathrm{T}^{2}$ 構造由来のピークが見られずシラノール基が存在しな いことが確認され，POSS ユニットだけで構成されたポリ マーの形成が示唆された。また，これら 2 本のピークの積 分比から $\mathrm{T}_{8}$ ユニットの POSS 構造が主成分であることが 分かった。溶離液としてクロロホルムを使用した GPC 測 定により分子量を算出するために，ドデカノイルクロリド との反応により生成物の疎水化を行った。この生成物の GPC 測定より POSS が平均 10 個程度連結したポリマー であることが分かり $\left(M_{\mathrm{w}}=3.2 \times 10^{4}\right)$ ，また疎水化する前 のポリマーの水溶液をガラス基板上で乾燥したところ透明 な膜を形成し，さらにXRD 測定からは非晶質な材料であ ることが明らかとなった。一方, POSS Polymer の熱分 解温度 $\left(T_{\mathrm{d} 5}\right)$ は $351^{\circ} \mathrm{C}$ であり熱安定性に優れる材料である ことが分かった。

\subsection{POSS 構造を含むイオン液体の合成}

イオン液体は多分野への応用の可能性から多くの関心を 集めている。しかし，シロキサン結合等の無機成分を含む イオン液体の報告例は少ない。このような無機成分をより 多く含むイオン液体は耐熱性や難燃性の向上が予想され, より安全な電解質やグリーンソルベント等への利用が期待 される。このような背景より，無機骨格材料である POSS を含むイオン液体の合成が中條・田中らによって初めて報 告された ${ }^{44)}$ 。このPOSS は側鎖にカルボキシレートアニ
オン，対イオンにイミダゾリウムカチオンを有し，室温付 近に融点 $\left(T_{\mathrm{m}}\right)$ を持つイオン液体の性質を示すことが見出 されている。

一方で筆者らは，トリメチル [3-(トリエトキシシリル) プロピル］アンモニウムクロリド $(\mathrm{TTACl})$ や 1 -メチル $-3-[3-($ トリエトキシシリル)プロピル $]$ イミダゾリウム クロリド（MTICl）を原料として用い，触媒に超強酸の ビス（トリフルオロメタンスルホニル）イミド $\left(\operatorname{HNTf}_{2}\right)$ を用いた加水分解/縮合反応を水中で行ったところ，偶然

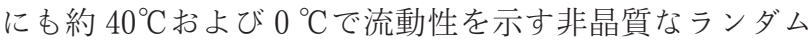
型オリゴ $\mathrm{SQ}$ 構造を有するイオン液体（Am-RandomSQ-IL および Im-Random-SQ-IL）が得られることを 見出している ${ }^{45,46)}$ 。一方, 反応溶媒を水のみから水/メ夕 ノール混合溶媒に代えて同様の反応を行うと，結晶性の POSS（Am-Cage-SQ-IL および Im-Cage-SQ-IL）が それぞれ簡便に得られることも見出している(図 7a,b) ${ }^{45,46) 。 ~}$ しかし，これらの結晶性 POSS は $T_{\mathrm{m}}\left(172^{\circ} \mathrm{C}\right.$ 抢よび $\left.105^{\circ} \mathrm{C}\right)$ 程度まで加熱しないと流動性を示さず，比較的高い流動温 度が様々な応用における課題であった。

そこで前述の 2 種の側鎖置換基を有する低結晶性 POSS の合成手法 (図 6c) ${ }^{40}$ ) に着目し，TTACl と MTICl からな る混合物の $\mathrm{HNTf}_{2}$ を触媒に用いた加水分解/縮合反応を 水/メタノール混合溶媒中で行ったところ，2 種の側鎖置 換基を有する室温イオン液体の性質を示す POSS (Amim -Cage-SQ-IL）が得られることを見出した（図 7c) ${ }^{47) 。 ~}$ ${ }^{29} \mathrm{Si} \mathrm{NMR} \mathrm{スペクトルからは} \mathrm{T}^{3}$ 構造由来のピークのみが 観測され，ピークの積分比より $\mathrm{T}_{8}$ が主生成物であること が確認された。DSC 測定より $-13^{\circ} \mathrm{C}$ にガラス転移点 $\left(T_{\mathrm{g}}\right)$ 由来のベースラインシフトが観測され， $T_{\mathrm{m}}$ 由来のピーク は観測されなかった。また流動温度を目視で確認したとこ

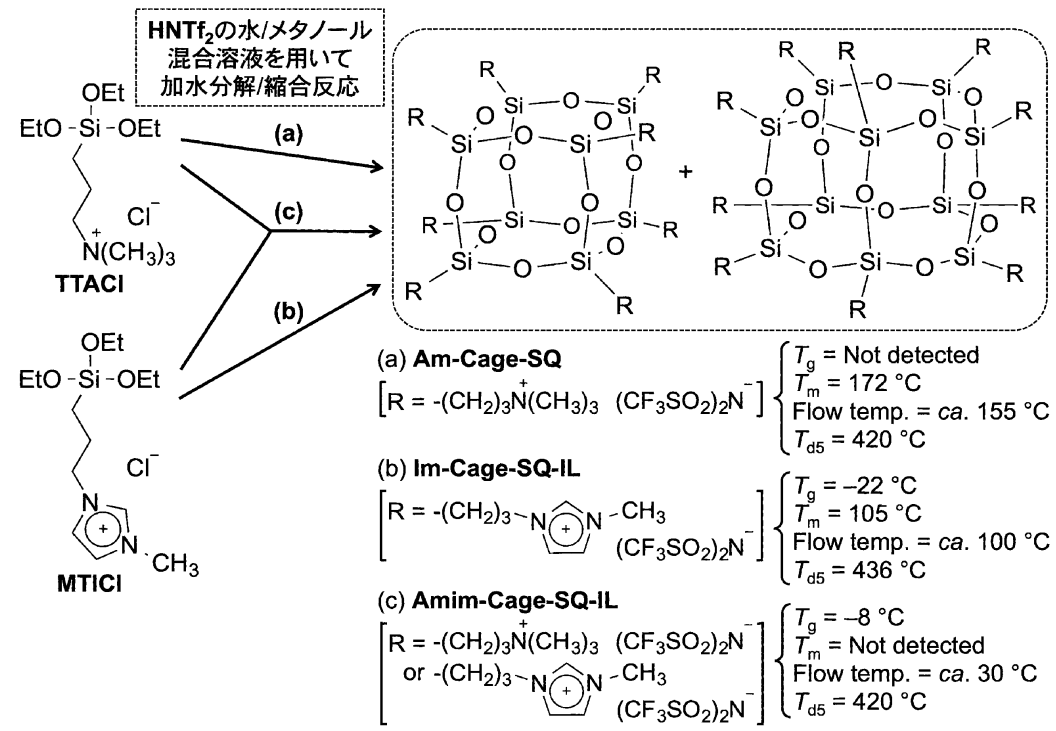

図 7 （a）四級アンモニウム塩含有 POSS：Am-Cage-SQ およびイオン液体の 性質を示す POSS : (b) Im-Cage-SQ-IL, (c) Amim-Cage-SQ-IL の合成 
ろ，30ㄷ上で明らかに流動性を示したことより，室温イ オン液体であることが分かった。すなわち, Amim-Cage -SQ-IL は 2 種の側鎖置換基が POSS の側鎖にランダム に配置したことで分子の対称性が低下し，結晶化が抑制さ れ $T_{\mathrm{m}}$ が消失し，その結果室温付近で流動性を示したと考 えている。

\section{4. おわりに}

本研究では, 反応中にイオンを形成する置換基をむつ有 機トリアルコキシシランを用いて加水分解/縮合反応を行 うことにより，ラダー状ポリ SQや POSS 誘導体のよう な構造制御された可溶性 SQ を比較的簡便に高収率で得ら れることを見出してきた。本稿で紹介したこれらの可溶性 SQ には, 成膜性や粘性を示すものもあり, 耐熱性や耐久 性等に優れる接着・粘着剤として今後の応用が期待される。

\section{謝辞}

本研究を遂行するにあたり, 共同研究者として御尽力い ただいた，井伊伸夫博士 (物質・材料研究機構), 敷中一 洋博士 (東京農工大学), 大下浄治教授 (広島大学), 水雲 智信博士（広島大学, 現サムスン), 杉岡卓央氏 (日本触 媒), 住田康隆氏 (日本触媒) および本研究に携わった研 究室の学生・卒業生・修了生に厚く御礼申し上げる。また 本研究の一部は, 科研費挑戦的萌芽研究 (No. 15K13711) の助成により行われたものであり，ここに感謝の意を表す。

\section{文献}

1）伊藤真樹監修, “シルセスキオキサン材料の最新技術と応用”, シーエムシー (2013).

2）金子芳郎, 化学と工業, 65, 694（2012）。

3) D. A. Loy, B. M. Baugher, C. R. Baugher, D. A. Schneider and K. Rahimian, Chem. Mater., 12, 3624 (2000).

4) J. F. Brown, Jr., L. H. Vogt, Jr., A. Katchman, J. W. Eustance and K. M. Kiser, J. Am. Chem. Soc., 82, 6194 (1960).

5) J. F. Brown, Jr., L. H. Vogt, Jr. and P. I. Prescott, J. Am. Chem. Soc., 86, 1120 (1964).

6) X. Zhang, P. Xie, Z. Shen, J. Jiang, C. Zhu, H. Li, T. Zhang, C. C. Han, L. Wan, S. Yan and R. Zhang, Angew. Chem. Int. Ed., 45, 3112 (2006).

7) S-S. Choi, H. S. Lee, S. S. Hwang, D. H. Choi and K-Y. Baek, J. Mater. Chem., 20, 9852 (2010).

8) Z. Ren, D. Sun, H. Li, Q. Fu, D. Ma, J. Zhang and S. Yan, Chem. Eur. J., 18, 4115 (2012).

9) J. D. Lichtenhan, Y. A. Otonari and M. J. Carr, Macromolecules, 28, 8435 (1995).

10) T. S. Haddad and J. D. Lichtenhan, Macromolecules, 29 , 7302 (1996).

11) A. Tsuchida, C. Bolln, F. G. Sernetz, H. Frey and R. Mulhaupt, Macromolecules, 30, 2818 (1997).

12) A. Lee and J. D. Lichtenhan, Macromolecules, 31, 4970 (1998).

13) P. T. Mather, H. G. Jeon, A. Romo-Uribe, T. S. Haddad and J. D. Lichtenhan, Macromolecules, 32, 1194 (1999).

14) K-M. Kim and Y. Chujo, J. Polym. Sci., Part A: Polym.
Chem., 39, 4035 (2001).

15) J. H. Jung and R. M. Laine, Macromolecules, 44, 7263 (2011).

16) S. Wu, T. Hayakawa, R. Kikuchi, S. J. Grunzinger, M. Kakimoto and H. Oikawa, Macromolecules, 40, 5698 (2007).

17) S. Wu, T. Hayakawa, M. Kakimoto and H. Oikawa, Macromolecules, 41, 3481 (2008).

18) M. Yoshimatsu, K. Komori, Y. Ohnagamitsu, N.Sueyoshi, N. Kawashima, S. Chinen, Y. Murakami, J. Izumi, D. Inoki, K. Sakai, T. Matsuo, K. Watanabe and M. Kunitake, Chem. Lett., 41, 622 (2012).

19) K. Wei, L. Wang and S. Zheng, Polym. Chem., 4, 1491 (2013).

20) T. Maegawa, Y. Irie, H. Fueno, K. Tanaka and K. Naka, Chem. Lett., 43, 1532 (2014).

21) T. Maegawa, Y. Irie, H. Imoto, H. Fueno, K. Tanaka and K. Naka, Polym. Chem., 6, 7500 (2015).

22) T. Maegawa, O. Miyashita, Y. Irie, H. Imotoa and K. Naka, RSC Adv., 6, 31751 (2016).

23) Y. Kaneko, N. Iyi, K. Kurashima, T. Matsumoto, T. Fujita and K. Kitamura, Chem. Mater., 16, 3417 (2004).

24) Y. Kaneko and N. Iyi, Z. Kristallogr., 222, 656 (2007).

25）金子芳郎，井伊伸夫，高分子論文集，67，280（2010）.

26) Y. Kaneko, H. Toyodome, M. Shoiriki and N. Iyi, Int. J. Polym. Sci., Article ID 684278 (2012).

27）金子芳郎，“シルセスキオキサン材料の最新技術と応用”, シーエムシー, p. 32 (2013).

28）金子芳郎, “ゾルーゲル法の最新応用と展望”，シーエムシー, p. 7 (2014).

29）金子芳郎，高分子論文集，71，443（2014）.

30）金子芳郎，ケイ素化学協会誌，32, 19 (2015).

31）金子芳郎, “水溶性高分子の最新動向”, シーエムシー, p. 156 (2015).

32) Y. Kaneko, N. Iyi, T. Matsumoto and K. Kitamura, Polymer, 46, 1828 (2005).

33) H. Toyodome, Y. Kaneko, K. Shikinaka and N. Iyi, Polymer, 53, 6021 (2012).

34) Y. Kaneko, H. Toyodome, T. Mizumo, K. Shikinaka and N. Iyi, Chem. Eur. J., 20, 9394 (2014).

35) Y. Kaneko, H. Imamura, T. Sugioka and Y. Sumida, Polymer, 92, 250 (2016).

36) S. Miyauchi, T. Sugioka, Y. Sumida and Y. Kaneko, Polymer, 66, 122 (2015).

37) D. B. Cordes, P. D. Lickiss and F. Rataboul, Chem. Rev., 110, 2081 (2010).

38) F. J. Feher and K. D. Wyndham, Chem. Commun., 323 (1998).

39) Y. Kaneko, M. Shoiriki and T. Mizumo, J. Mater. Chem., 22, 14475 (2012).

40) T. Tokunaga, M. Shoiriki, T. Mizumo and Y. Kaneko, J. Mater. Chem. C, 2, 2496 (2014).

41) H. Araki and K. Naka, Macromolecules, 44, 6039 (2011).

42) H. Araki and K. Naka, Polym. J., 44, 340 (2012).

43) T. Tokunaga, S. Koge, T. Mizumo, J. Ohshita and Y. Kaneko, Polym. Chem., 6, 3039 (2015).

44) K. Tanaka, F. Ishiguro and Y. Chujo, J. Am. Chem. Soc., 132, 17649 (2010).

45) T. Ishii, T. Mizumo and Y. Kaneko, Bull. Chem. Soc. Jpn., 87, 155 (2014).

46) T. Ishii, T. Enoki, T. Mizumo, J. Ohshita and Y. Kaneko, RSC Adv., 5, 15226 (2015).

47) A. Harada, S. Koge, J. Ohshita and Y. Kaneko, Bull. Chem. Soc. Jpn., 89, 1129 (2016). 